\title{
The Market Participant Doctrine and the Clear Statement Rule
}

\author{
David S. Bogen
}

\section{INTRODUCTION}

One of the most interesting developments in Commerce Clause jurisprudence is the market participant exception to the dormant Commerce Clause. ${ }^{1}$ The dormant Commerce Clause invalidates state regulations that discriminate against or impose an undue burden on interstate commerce. Unless Congress approves of such regulations, they conflict with the policies behind the grant of power to Congress to regulate commerce among the several states. ${ }^{2}$ According to the market participant doctrine, however, the state does not violate the dormant Commerce Clause by favoring its own citizens and companies when it buys or sells goods or services. ${ }^{3}$

Four Supreme Court decisions, each written by a different justice, focus on the market participant doctrine. The authors of each of the first three opinions dissented in the next case, ${ }^{4}$ and although the Court failed

\footnotetext{
$\dagger$ Professor of Law, University of Maryland School of Law. B.A., Harvard College; LL.B., Harvard Law School; LL.M., N.Y.U. Law School. Thanks to Professors Anuj Desai, William Reynolds, Dan Gilman and Alan Hornstein for their comments and to Susan McCarty '05 and Marck Stanley '07 for research assistance.

1. The term "dormant Commerce Clause" was first used in Hill v. Florida, 325 U.S. 538, 547 (1945) (Frankfurter, J., dissenting), first mentioned in a majority opinion by Justice Marshall in Merrion v. Jicarrilla Apache Tribe, 455 U.S. 130, 154 (1982), and first used in both majority and dissent in White v. Mass. Council of Construction Employers, Inc., 460 U.S. 204, 213, 220 (1983). It has since become common for the Court to refer to the negative implications of the Commerce Clause with this phrase.

2. H.P. Hood \& Sons, Inc. v. Du Mond, 336 U.S. 525, 537-38 (1949); City of Philadelphia v. New Jersey, 437 U.S. 617, 623-24 (1978).

3. See Reeves, Inc. v. Stake, 447 U.S. 429, 436-37, 440 (1980) (holding that South Dakota may prefer South Dakota customers in sale of state government-produced cement); Hughes v. Alexandria Scrap Corp., 426 U.S. 794, 807-09 (1976) (holding that Maryland may make it more expensive for out-of-state companies to obtain bounty from state government for converting Maryland titled junk cars into scrap).

4. Justice Powell authored the first market participant decision, Hughes v. Alexandria Scrap Corp., 426 U.S. 794 (1976), but dissented in Reeves, 447 U.S. at 447. Justice Blackmun, the author
} 
to muster a majority in the fourth case, the author of the plurality opinion had dissented from each of the three previous decisions. ${ }^{5}$ Because the Court lacks any clear agreement on the rationale for the doctrine, its limits remain uncertain. ${ }^{6}$

The state achieves market discrimination by regulations binding on its employees - so why is the regulation of state employees engaged in state business permissible while regulation of private companies to the same effect would be fatally flawed? The dissenters in Reeves argue that the state should be judged by the same standards and under the same restrictions when it regulates its employees and when it regulates others. ${ }^{7}$ After all, when the state is the sole or primary participant in a market, its decision to discriminate in favor of its residents operates as effectively as a regulation of the market. ${ }^{8}$

On the other hand, the Court has refused to find that the state was a market participant when it conditioned sales on the subsequent behavior of the purchaser. ${ }^{9}$ The plurality in South-Central Timber said such "downstream regulation" was not exempt from the Commerce Clause. ${ }^{10}$

of Reeves, dissented in White, 460 U.S. at 215. Justice Rehnquist, the author of White, dissented in South-Central Timber Dev., Inc. v. Wunnicke, 467 U.S. 82, 101 (1984). The plurality opinion in South-Central Timber was written by Justice White, a dissenter in Hughes, Reeves, and White.

5. Justice Marshall did not participate in South-Central Timber. 467 U.S. at 101. Justices Blackmun, Brennan, and Stevens agreed with Justice White that the state was not exempt from dormant Commerce Clause analysis. Id. at 93-99. Chief Justice Burger and Justice Powell concurred in the order, but would have remanded the case to allow the lower court to determine whether the state was acting as a market participant. Id. at 101. Justices Rehnquist and O'Connor would have found that the state was participating in the market. Id. at 101-03. Thus, there was no majority on whether the state was acting as a market participant in the case.

6. The last fully considered pronouncement of the Supreme Court occurred over twenty years ago in South-Central Timber. Much of the subsequent litigation in lower courts, particularly in the Second and Eighth Circuits, has been over arrangements between government and waste processors that limit the discretion of the waste processor to deal with others. See Huish Detergents, Inc. v. Warren County, 214 F.3d 707 (6th Cir. 2000); Inc. Vill. of Rockville Ctr. v. Town of Hempstead, 196 F.3d 395 (2d Cir. 1999); Automated Salvage Transp., Inc. v. Wheelabrator Envtl. Sys., 155 F.3d 59 (2d Cir. 1998); Nat'l Solid Waste Mgmt. Ass'n v. Williams, 146 F.3d 595 (8th Cir. 1998); Red River Serv. Corp. v. City of Minot, 146 F.3d 583 (8th Cir. 1998); Sal Tinnerello \& Sons, Inc. v. Town of Stonington, 141 F.3d 46 (2d Cir. 1998); SSC Corp. v. Town of Smithtown, 66 F.3d 502 (2d Cir. 1995); USA Recycling, Inc. v. Town of Babylon, 66 F.3d 1272 (2d Cir. 1995).

7. See Reeves, 447 U.S. at 449-50 (Powell, J., joined by Brennan, White \& Stevens, JJ., dissenting) (Commerce Clause designed to maintain national market and defeat economic provincialism).

8. Id. at 453 (Powell, J., joined by Brennan, White \& Stevens, JJ., dissenting).

9. South-Central Timber Dev., Inc. v. Wunnicke, 467 U.S. 82, 98-99 (1984).

10. Id. at 99. Chief Justice Burger and Justice Powell concurred in the order, which remanded the case to the Court of Appeals for proceedings consistent with the plurality opinion, but would have remanded the case to allow the lower court to determine whether the state was acting as a market participant. Id. at 101 (Burger, C.J., joined by Powell, J., concurring). Powell and Burger agreed with the majority that the federal government had not authorized the state's behavior, and were unwilling to join the dissent's position upholding the court below on the grounds that the state was a 
Dissenters this time pointed out that private market participants can condition their sales on the subsequent behavior of their buyers-so conditions on sales are just as much a part of market behavior as is the choice of the buyer. ${ }^{11}$

The Court distinguishes between regulation and market participation, but the exception to the market participant doctrine for "downstream regulation" has not been well explained. For example, when a mayor issued an executive order that required firms contracting with the city to use city residents for work on city projects, the executive order applied to contracts to which the city was not a party, i.e., those between the contractor and its employees. ${ }^{12}$ Nevertheless, the Court held that the city acted as a market participant. ${ }^{13}$ On the other hand, the Court invalidated as a "downstream regulation" a provision in a contract between the state and purchasers of timber from the state that required the purchaser to process the timber in the state: "Unless the 'market' is relatively narrowly defined, the doctrine has the potential of swallowing up the rule that States may not impose substantial burdens on interstate commerce even if they act with the permissible state purpose of fostering local industry." 14 But if the definition of the market is tied to the burden on interstate commerce, the analysis may turn on fact-specific economic determinations of how large the impact on interstate commerce might be. Such an analysis could become very difficult to manage. A different explanation focuses less on the effect on interstate commerce, and more on the federal government regulating the state.

The market participant doctrine is best understood as an analogue to the clear statement rule, which asserts that Congressional enactments should not be construed to apply to state government operations unless Congress has clearly stated that it intends such an application. ${ }^{15}$ Unless the state violates constitutionally or congressionally imposed restrictions on its power, it can determine with whom it will contract. There is no relevant express constitutional limit on the state's power, and "if Congress intends to alter the 'usual constitutional balance between the States and the Federal Government,' it must make its intention to do so 'unmis-

market participant. They joined in the order to enable the Court of Appeals to resolve the case, but the case did not resolve the issue for the future. Id.

11. Id. at 101-02 (Rehnquist, J., joined by $\mathrm{O}^{\prime}$ Connor, J., dissenting).

12. White v. Mass. Council of Constr. Employers, Inc., 460 U.S. 204, 205 n.1 (1983).

13. Id. at 215.

14. South-Central Timber, 467 U.S. at 97-98.

15. Gregory v. Ashcroft, 501 U.S. 452, 460, 467 (1991) (holding that the Age Discrimination in Employment Act of 1967 (ADEA) does not apply to state judges). 
takably clear in the language of the statute." ${ }^{\prime \prime 16}$ Respect for state sovereignty requires that Congress make a deliberate and considered decision before a federal statute will be interpreted to impose a duty on state officials. Congressional silence cannot be the clear statement required to provoke such a confrontation. If Congress must be clear for its enactments to apply to the state, then, likewise, the dormant Commerce Clause should not be relevant to purchase and sale decisions of the state.

When the state acts as a market regulator, the dormant Commerce Clause invalidates discriminatory regulation without the need for an order against the state. The courts simply refuse to enforce the state law on the ground that it is unconstitutional. When the state acts as a market participant, however, the court would have to direct its order against the state or its officials to negate the discrimination. This produces a direct confrontation with the state, the same kind of confrontation the clear statement rule was designed to avoid.

Part II of this article examines the theory of the dormant Commerce Clause, and concludes that it is a presumption of congressional intent based on a substantive policy choice to limit discrimination against interstate commerce. Part III looks at the justifications offered for the market participant exception, which permits states to discriminate in favor of their own people in state purchases and sales, and suggests that justifications offered by the Court and commentators are conclusory or inadequately explained. Part IV explains the clear statement rule, which is concerned with intrusions into state sovereignty, and shows how that rule applies to the dormant Commerce Clause when the government participates in the market. Part $\mathrm{V}$ discusses the exception for downstream regulation of interstate commerce, in which the concern for intrusion into state sovereignty does not apply. Part VI examines other constitutional clauses that may prohibit states from using their power to purchase or sell goods or services in order to discriminate against commerce from other states. This Part concludes that the market participant doctrine, which prevents the federal government from ordering states to make specific purchases or sales without a congressional determination that such regulation is necessary, is a sound application of the clear statement rule that poses no threat to interstate commerce in the light of other safeguards.

16. Will v. Mich. Dep't of State Police, 491 U.S. 58, 65 (1989) (quoting Atascadero State Hosp. v. Scanlon, 473 U.S. 234, 242 (1985)) (finding a state is not a person under 42 U.S.C. $\S 1983$ ). 


\section{THE THEORY OF THE DORMANT COMMERCE CLAUSE}

Article I of the United States Constitution confers power on Congress to regulate commerce among the several states. ${ }^{17}$ Federal regulation pursuant to this Article preempts any conflicting state regulation. ${ }^{18}$ Where there is no express preemption, the Court must determine whether the state law conflicts with the Congressional purpose in enacting a federal law. ${ }^{19}$ If Congress has not specifically addressed the issue, the Court will impute intention to preempt or not to preempt. Although the Court has stated that there is a presumption against preemption, ${ }^{20}$ it has still often found state law preempted by implications from federal action. ${ }^{21}$ As in contract interpretation, a term may be a divination of implicit intent or imposed for policy reasons where no actual intent exists. ${ }^{22}$

But what if there is no relevant federal regulation? The Supreme Court has taken a variety of positions - beginning with the view of Justice William Johnson, concurring in Gibbons v. Ogden, ${ }^{23}$ that state regulation of interstate commerce is inconsistent with the grant of regulatory power to the federal government. This theory proved difficult to reconcile with the acknowledged power of the states to regulate interstate

\section{U.S. CONST. art. I, $\S 8, \mathrm{cl} .3$.}

18. U.S. CONST. art. VI, $\S 2$ ("This Constitution, and the Laws of the United States which shall be made in Pursuance thereof . . . shall be the supreme Law of the Land; and the Judges in every State shall be bound thereby, any Thing in the Constitution or Laws of any State to the Contrary notwithstanding."). See also Gonzales v. Raich, 125 S. Ct. 2195 (2005) (holding that Congressional power under the Commerce Clause, in conjunction with the Necessary and Proper Clause, includes power to prohibit local cultivation and use of marijuana for medicinal purposes even if authorized by state law); Gibbons v. Ogden, 22 U.S. (9 Wheat.) 1, 211 (1824).

19. Gade v. Nat'l Solid Waste Mgmt. Ass'n, 505 U.S. 88, 108 (1992); Geier v. Am. Honda Motor Co., 529 U.S. 861,894 (2000). See generally Marin R. Scordato, Federal Preemption of State Tort Claims, 35 U.C. DAVIS L. REV. 1 (2001).

20. Bates v. Dow Agrosciences LLC, 125 S. Ct. 1788, 1801 (2005).

21. E.g., Lorillard Tobacco Co. v. Reilly, 533 U.S. 525 (2001) (finding preemption of state zoning rule limiting location of cigarette ads by federal statute regulating cigarette labels); United States v. Locke, 529 U.S. 89 (2000) (finding preemption of state regulation of oil tankers by federal law implied where there was history of significant federal regulation); Crosby v. Nat'l Foreign Trade Council, 530 U.S. 363 (2000) (finding state statute barring state government deals with Burma preempted by federal statute delegating power to President to impose sanctions on Burma).

22. See E. Allan Farnsworth, Contracts 452, 459-61 (4th ed. 2004). Thus, the Court refused to apply the presumption against preemption where the area was not traditionally regulated by the state, but subject to federal government action. See Locke, 529 U.S. at 108. However, characterization of the area by the court, e.g., whether the law in Lorillard was a zoning law or a regulation of advertising, is critical to this conclusion. Lorillard, 533 U.S. at 548-51.

23. 22 U.S. (9 Wheat.) 1, 227 (1824) (Johnson, J., concurring) ("[T]he grant of this power carries with it the whole subject, leaving nothing for the State to act upon."). Marshall's opinion suggested exclusivity, but ultimately held that the state law was preempted by a federal statute. $I d$. at 221. 
commerce to protect the health and safety of their citizens. ${ }^{24}$ Furthermore, it would invalidate state laws that facilitated interstate commerce-a result hard to square with the purpose of the Clause or a practical approach to the Constitution.

In The License Cases, Justice Roger Taney countered with the view that the power to regulate interstate commerce was concurrent, and that states were free to regulate unless specifically overridden by federal legislation. ${ }^{25}$ But eliminating discriminatory state laws was one of the main reasons for granting Congress the power. ${ }^{26}$ Finding such laws constitutional could encourage the kind of interstate warfare that led the Court to invalidate the steamboat licenses in Gibbons v. Ogden. ${ }^{27}$ Thus, like the exclusive power theory, a concurrent power interpretation frustrated the purpose of the Clause and created an impractical rule.

In Cooley v. Board of Wardens, ${ }^{28}$ Justice Benjamin Curtis argued that interstate commerce was of two types, and that the grant of power to Congress affected them differently: states lacked power to regulate commerce that required uniformity, but other commerce was subject to concurrent power. ${ }^{29}$ Thus, under Curtis's approach, state power to regulate interstate commerce depended on the type of interstate commerce regulated. Cooley enabled the Court to escape the trap of an all-ornothing approach-either exclusive or concurrent power - and pointed the way for the Court to distinguish between state regulations that contravened the purpose of the grant of power to Congress and those that did not. The Court later found that the purpose of the grant was, in part, to end the economic protectionism by states that burdened interstate commerce, ${ }^{30}$ and now focuses on the nature of the state regulation to determine whether it is discriminatory or imposes an undue burden on interstate commerce.

24. See Willson v. Black Bird Creek Marsh Co., 27 U.S. (2 Pet.) 245, 251-52 (1829) (finding state authorization of the dam of a navigable creek was justified as an exercise of police power and not as an exercise of the power to regulate interstate commerce).

25. 46 U.S. (5 How.) 504, 579 (1847) ("[T] he State may nevertheless, for the safety or convenience of trade, or for the protection of the health of its citizens, make regulations of commerce for its own ports and harbours, and for its own territory; and such regulations are valid unless they come in conflict with a law of Congress.").

26. "The same want of a general power over Commerce, led to an exercise of the power separately, by the States, which not only proved abortive, but engendered rival, conflicting and angry regulations." James MADISON, Notes OF DEBATES IN THE FEDERAL CONVENTION OF 178714 (Ohio University Press 1966) (1840).

27. 22 U.S. (9 Wheat.) 1 (1824).

28. 53 U.S. (12 How.) 299 (1851).

29. Id. at 319.

30. See, e.g., H.P. Hood \& Sons, Inc. v. Du Mond, 336 U.S. 525, 535 (1949). 
Justice Curtis's solution has difficulties of its own: it is linguistically implausible, and its strong view of exclusive power is impracticable. Curtis wrote: "If the Constitution excluded the States from making any law regulating commerce, certainly Congress cannot regrant, or in any manner reconvey to the States that power." ${ }^{31}$ Congress cannot normally enable a state to violate constitutional limits unless the constitutional restriction expressly permits congressional consent. ${ }^{32}$ If the Court holds that the Constitution prevents a state from prohibiting the importation of liquor from another state in its original package, ${ }^{33}$ Congress should not be able to permit such state laws. Yet that is exactly what Congress has done, and with the Court's approval. ${ }^{34}$

Linguistically, it is difficult to see why the grant of power to regulate commerce should preclude Congress from allowing some state regulations and not others. It seems strange indeed to read Article I as limiting Congressional power over interstate commerce. Further, the line drawn by the Court between permissible and impermissible state regulation seems to be a debatable one, rooted more on the facts of particular cases than on express constitutional language. It is unwise to make such a line a fixed constitutional principle, especially when later federal legislation states that state regulation is appropriate. Federal authorizing legislation demonstrates that state regulation is tolerable to the Union and that the coordinated decision of the nation finds state regulation preferable. Thus, the Court has held that Congress may permit laws that would otherwise violate the dormant Commerce Clause, ${ }^{35}$ and the Court will, in all likelihood, continue to so hold.

The Court continues to rely on implications from the Commerce Clause to invalidate state laws." "[D]iscrimination against out-of-state

31. Cooley, 53 U.S. (12 How.) at 318.

32. Thus, Norman Williams argues that Congress must adopt state laws and cannot authorize states to enact laws that would otherwise violate the dormant Commerce Clause. Norman R. Williams, Why Congress May Not "Overrule" the Dormant Commerce Clause, 53 UCLA L. REv. 153, 230-35, 238 (2005).

33. Leisy v. Hardin, 135 U.S. 100, 124-25 (1890).

34. Wilson Act of 1890, 27 U.S.C. $§ 121$ (2000) (upheld in In re Rahrer, 140 U.S. 545 (1891)); Webb-Kenyon Act of 1913, 27 U.S.C. $\S 122$ (2000) (upheld in Clark Distilling Co. v. W. Md. Ry. Co., 242 U.S. 311 (1917)).

35. W. \& S. Life Ins. Co. v. State Bd. of Equalization, 451 U.S. 648, 652-53 (1981) (finding that the federal statute validly permitted states to discriminate against interstate commerce in the insurance industry).

36. Granholm v. Heald, 125 S. Ct. 1885, 1892 (2005) (finding that the Twenty-First Amendment did not authorize or permit the State to discriminate against interstate commerce contrary to the dormant Commerce Clause). 
goods is disfavored." ${ }^{37}$ The Court even talks as though the Constitutional provision itself forbade the state from enacting such a law, saying that the laws were "in violation of the Commerce Clause." ${ }^{\text {"38 }}$ But under existing precedent, it violates the Commerce Clause only in the absence of Congressional approval. ${ }^{39}$

Rather than saying that the Constitution prohibits the state from acting, it makes more sense to say that the Constitution informs the Court's interpretation of the will of Congress. If the framers of the Constitution wanted to impose a restriction on state power, they knew how to make it express; if they wanted to make the restriction subject to Congressional assent, they knew how to do so. ${ }^{40}$ However, the Commerce Clause does not expressly restrict the state or provide for congressional consent. Thus, it is easier to read the grant of power to Congress as empowering Congress to control interstate commerce, and to consider discriminatory state laws as violations of the will of Congress. ${ }^{41}$ In theory, the basis for the invalidation is that the federal government would not want states to discriminate against other states or to unduly burden interstate commerce, because ending such burdens was a reason for the grant to the federal government of power over interstate commerce. ${ }^{42}$

Although some commentators complain that Congress should not be held to be saying or doing anything under the Commerce Clause when

37. Id. at 1901 (noting that earlier federal statutes permitting states to prohibit the importation of liquor from other states did not allow states to discriminate in favor of liquor in their home market).

38. Id. at 1892 .

39. Clark Distilling, 242 U.S. at 328-29; Prudential Ins. Co v. Benjamin, 328 U.S. 408, 423-25 (1946); W. \& S. Life Ins., 451 U.S. at 652-53.

40. The Constitution expressly imposes some restrictions on states that permit action with congressional consent. The consent of Congress is necessary for a variety of state actions-interstate compacts, war, levying imposts on imports or exports, etc. U.S. CoNST. art. I, § 10, cls. 2-3.

41. "[I]n the absence of affirmative consent, a Congressional negative will be presumed in the courts against state action which in its effect upon interstate commerce constitutes an unreasonable interference with national interests, the presumption being rebuttable at the pleasure of Congress." Noel T. Dowling, Interstate Commerce and State Power, 27 VA. L. REV. 1, 20 (1940).

42. The precise standard for application of the Commerce Clause is beyond the scope of this Article, but it has been the subject of heated discussion both on and off the Court. Thus, Justice Scalia has said that he would not find any dormant Commerce Clause implicit in the Constitution as an initial matter and that, as a matter of stare decisis, discrimination is the only acceptable basis for invalidating state laws. Tyler Pipe Indus., Inc. v. Wash. State Dep't of Revenue, 483 U.S. 232, 265 (1987) (Scalia, J., dissenting). Scalia would also abandon the undue burden balancing test. Bendix Autolite Corp. v. Midwesco Enter., Inc., 486 U.S. 888, 897 (1988) (Scalia, J., concurring). See also Daniel A. Farber, State Regulation and the Dormant Commerce Clause, 3 CONST. COMMENT. 395 (1986); Donald H. Regan, The Supreme Court and State Protectionism: Making Sense of the Dormant Commerce Clause, 84 MiCH. L. REV. 1091 (1986); Julian N. Eule, Laying the Dormant Commerce Clause to Rest, 91 YALE L.J. 425 (1982). 
it fails to act, ${ }^{43}$ the implication of a federal prohibition by silence seems the best way to make the doctrine fit the language of the Constitution. ${ }^{44}$ It is not that Congress actually intends to forbid discriminatory action by the state, but rather that, in light of the purpose of the Commerce Clause to destroy barriers, the Court should, as a matter of policy, presume such an intention in the absence of positive action. ${ }^{45}$ By understanding the dormant Commerce Clause as a presumption of congressional intent based on underlying policies, the dormant Commerce Clause doctrine can continue to serve its function of protecting the Union while remaining flexible.

It seems likely that the dormant Commerce Clause has contributed to the growth of the economy. ${ }^{46}$ More importantly, it has promoted relationships between the states by invalidating state laws that would undermine the laws and practices of other states that facilitate commerce. ${ }^{47}$ Congress has accepted the dormant Commerce Clause as an appropriate

43. "The obvious flaw in this concept is that congressional silence, in the end, means only that Congress has not decided to legislate. Interpreting what Congress means when it has spoken is often difficult enough; to determine what Congress means when it has said nothing at all is impossible." Farber, supra note 42 , at 396 n.8.

44. Professor Williams suggests that the silence of Congress is not a "law" pursuant to the Constitution and thus is not entitled to prevail over state law. Williams, supra note 32, at 182-83. However, judicial decisions of the federal court pursuant to the Constitution are law, so the Supremacy argument is a red herring. The real question is whether the dormant Commerce Clause as a presumption of congressional intent is the best interpretation of that clause.

Professor Williams also argues that a presumption that the silence of Congress bars state laws in an area subverts state sovereignty because the difficulty in enacting a federal law tilts the legislative process against the state. Id. at 183-84. However, treating the dormant Commerce Clause as a constitutional limit instead of a statutory presumption imposes the same limits on state action, but also creates headwinds against federal approval of the state's acts.

Professor Williams further argues that no inferences should be drawn about Congressional intent, and that the prohibitions of the dormant Commerce Clause should flow from the Constitution itself. Id. at 182-83. The basic policy support for this view is that a constitutional limit is the strongest bulwark against economic protectionism and the Commerce Clause was adopted to eliminate that protectionism. As the text of this Article indicates, Professor Williams' rigid Cooley-like division seems misplaced linguistically and pragmatically. As an institutional matter, the use of the Commerce Clause as a limit on Congress seems contrary to the language of the Clause and the respect for the states needed to ensure passage of the Constitution.

45. This resembles the behavior of courts generally in supplying default terms for omitted terms in contract cases. Although the parties are silent on the situation, a term may be supplied to satisfy basic principles of justice, or because a well known default term accords with the expectations of the parties. See FARNSWORTH, supra note 22, at 486-87.

46. "The material success that has come to inhabitants of the states which make up this federal free trade unit has been the most impressive in the history of commerce, but the established interdependence of the states only emphasizes the necessity of protecting interstate movement of goods against local burdens and repressions." Hood v. Du Mond, 336 U.S. 525, 539 (1939). See also Donald H. Regan, The Supreme Court and State Protectionism: Making Sense of the Dormant Commerce Clause, 84 MiCH. L. REv. 1091, 1118 (1986).

47. Maxwell L. Stearns, A Beautiful Mend: A Game Theoretical Analysis of the Dormant Commerce Clause Doctrine, 45 WM. \& MARY L. REV. 1, 75 (2003). 
default principle: although Congress may occasionally attempt to permit specific protectionist behavior by states, it has made no effort to reverse the general judicial presumption of the dormant Commerce Clause. Whatever the merits of the Court's initial decision, it is appropriate today to uphold the dormant Commerce Clause principle that presumes that state discrimination against interstate commerce contravenes the purpose of the congressional grant.

\section{THE MARKET PARTICIPANT EXCEPTION}

The Court has found that the dormant Commerce Clause does not forbid discriminatory action by the state when the state acts as a market participant. ${ }^{48}$ It has justified this exception to the dormant Commerce Clause both historically ${ }^{49}$ - the Clause was not directed at this type of behavior - and politically ${ }^{50}$ - its application to the state's participation in the market would cause a variety of harms. Unfortunately, the Court's purpose analysis is superficial, and its supporting justifications are either inapt or insufficiently articulated.

\section{A. The Purpose of the Commerce Clause}

The market participant exception to the dormant Commerce Clause was initially rooted in the Court's purpose analysis. In Hughes v. Alexandria Scrap Corp., ${ }^{51}$ the Court found the dormant Commerce Clause inapplicable to a Maryland law that gave companies located in the state an advantage in obtaining the bounty Maryland paid to companies who processed abandoned cars as scrap. The trial court struck down the Maryland law as an improper burden on interstate commerce because it discouraged scrap suppliers from having the cars processed out of the state. ${ }^{52}$ The Supreme Court reversed on the grounds that Maryland's bounty system was not a regulation of the market, but was instead a means of participating in the market to bid up the price of the commodity. ${ }^{53}$ The Court treated the Maryland bounty as the purchase of the scrap processing services, and held that "[n]othing in the purposes animating the Commerce Clause prohibits a State, in the absence of congressional

48. Hughes v. Alexandria Scrap Corp., 426 U.S. 794, 810 (1976); Reeves, Inc. v. Stake, 447 U.S. 429, 436-37 (1980); White v. Mass. Council of Constr. Employers, Inc., 460 U.S. 204, 206-08, 214-15 (1983).

49. Hughes, 426 U.S. at 810 ; Reeves, 447 U.S. at 435.

50. Reeves, 447 U.S. at 438-9.

51. 426 U.S. 794 (1976).

52. 391 F. Supp. 46, 63 (D. Md. 1975).

53. Hughes, 426 U.S. at 806. 
action, from participating in the market and exercising the right to favor its own citizens over others.",54

Four of the justices did not read the purpose of the Clause in quite the same way. Justice Stevens concurred on the grounds that the commerce in abandoned hulk processing would not exist without the Maryland program. ${ }^{55} \mathrm{He}$ distinguished between state participation in commerce that flourishes in a free market, and commerce that exists only because of a state subsidy. ${ }^{56}$ Justice Brennan, joined by Justices White and Marshall, dissented, arguing that the purpose of the Commerce Clause was to prevent states from promoting their own economic advantages by curtailing or burdening interstate commerce. ${ }^{57}$ Thus, according to the dissenters, the "market participant" doctrine was inconsistent with accepted Commerce Clause principles opposing economic protectionism. $^{58}$

Justice Powell, the author of the majority opinion in Hughes, dissented four years later in Reeves $v$. Stake, ${ }^{59}$ the next case involving the market participant doctrine. South Dakota built a cement plant and favored in-state cement buyers during a time of shortage. ${ }^{60}$ Powell, joined by Justices Stevens, White, and Brennan, distinguished Hughes as involving the "traditional government function" of a subsidy program, and said that South Dakota was entering the private market and operating a commercial enterprise for the benefit of its private citizens. ${ }^{61}$ That, Powell said, was the type of economic protectionism that violated "the constitutional policy against economic Balkanization. ${ }^{, 62}$

The Reeves majority threw Powell's words in Hughes back at him, reiterating his earlier statement that nothing in the purposes of the Commerce Clause prevented states from favoring their own citizens over others when they participated in the market. ${ }^{63}$ According to the majority, South Dakota was simply participating in the market. ${ }^{64}$

The problem with the purpose analysis is that it operates only at the most specific level. State discrimination in taxation and regulation of the market may have led to the Commerce Clause, but the framers of the Clause did not discuss whether other forms of economic protectionism

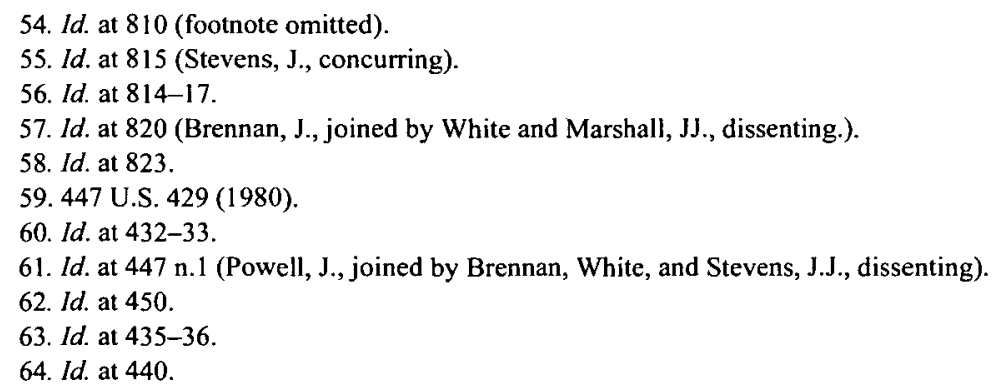


would be within its purpose. The dissenters in Reeves argued that the Commerce Clause was designed to deal with the market distortion produced by discriminatory regulation and taxation. ${ }^{65}$ Thus, behavior that posed no problem when the Constitution was adopted should be prohibited by the dormant Commerce Clause if it causes significant distortion today. ${ }^{66}$

State participation in the market is not immune from federal regulation pursuant to the Commerce Clause: the Clause is a grant of power to the federal government and does not expressly mention the powers of states. In conjunction with the Supremacy Clause, the Commerce Clause enables the federal government to regulate states when they impact interstate commerce, whether as regulator or participant, whether performing a traditional government function or acting in a proprietary role. For example, the Court has held that federal law preempted a state law on eligibility for purchases and sales from the state when the state excluded firms that had violated federal labor law. ${ }^{67}$ Similarly, federal sanctions against a nation preempted a state law that prohibited the state and its agencies from doing business with companies that did business with the sanctioned nation. ${ }^{68}$ In these cases, the state's decision to base its purchases and sales on a specific policy conflicted with a federal statute intended to occupy the field, and the Court invalidated the state's policy. A state's decision to limit its purchases and sales to its residents is also a policy decision; the question is whether it conflicts with federal policy when there is no relevant federal statute. Those who oppose the market participant doctrine argue that federal policy opposes economic protectionism unless there is some specific reason to find the dormant Commerce Clause inapplicable. ${ }^{69}$

65. Reeves, Inc. v. Stake, 447 U.S. 429, 449-50 (1980) (Powell, J., joined by Brennan, White, and Stevens, JJ., dissenting).

66. This is the basic point in a slew of articles that criticize the market participant doctrine as unwarranted. See, e.g., Theodore Y. Blumoff, The State Proprietary Exception to the Dormant Commerce Clause: A Persistent Nineteenth Century Anomaly, 9 S. ILL. U. L.J. 73 (1984); Barton B. Clark, Comment, Give 'Em Enough Rope: States, Subdivisions and the Market Participant Exception to the Dormant Commerce Clause, 60 U. CHI. L. REv. 615 (1993); Carol A. Fortine, Note, The Commerce Clause and Federalism: Implications for State Control of Natural Resources, 50 GEO. WASH. L. REV. 601 (1982); Karl Manheim, New-Age Federalism and the Market Participant Doctrine, 22 ARIZ. ST. L.J. 559 (1990); Michael J. Polelle, A Critique of the Market Participation Exception, 15 WhITTIER L. Rev. 647 (1994); Barbara J. Redman, The Market Regulator-Market Participant Distinction and Supreme Court Vigilance over Discriminatory State Programs: Does Economic Theory Justify the Judicial Effort? 25 AM. BUS. L.J. 585 (1988); A. Dan Tarlock, National Power, State Resource Sovereignty and Federalism in the 1980's: Scaling America's Magic Mountain, 32 U. KAN. L. REV. 111 (1983).

67. Wis. Dep't of Indus. v. Gould, Inc., 475 U.S. 282, 289-91 (1986).

68. Crosby v. Nat'l Foreign Trade Council, 530 U.S. 363, 372-74 (2000).

69. See note 66, supra. 


\section{B. The Court's Supporting Reasons}

In Reeves, the court set forth five reasons in support of its decision that the dormant Commerce Clause did not apply:

Restraint in this area is also counseled by considerations of state sovereignty, the role of each State "as guardian and trustee for its people," and "the long recognized right of trader or manufacturer, engaged in an entirely private business, freely to exercise his own independent discretion as to parties with whom he will deal." Moreover, state proprietary activities may be, and often are, burdened with the same restrictions imposed on private market participants. Evenhandedness suggests that, when acting as proprietors, States should similarly share existing freedoms from federal constraints, including the inherent limits of the Commerce Clause. Finally, as this case illustrates, the competing considerations in cases involving state proprietary action often will be subtle, complex, politically charged, and difficult to assess under traditional Commerce Clause analysis. Given these factors, Alexandria Scrap wisely recognizes that, as a rule, the adjustment of interests in this context is a task better suited for Congress than this Court. ${ }^{70}$

The first two reasons the Court gives in support of the market participant doctrine, (1) considerations of state sovereignty and (2) the role of the state as guardian of its people, focus on the distinctive nature of the state. The next two reasons, (3) the right of the trader to decide with whom to deal and (4) evenhandedness in burdens on trade, suggest that states should be treated like other entities in the market. The final reason is (5) the difficulty of balancing interests of the state and interstate commerce in this setting. None of these reasons, however, have been explained sufficiently to justify the market participant doctrine.

\section{Considerations of State Sovereignty}

The Court in Reeves asserted that restraint was called for by considerations of state sovereignty. ${ }^{71}$ This is a strong argument because state sovereignty underlies the clear statement rule $;^{72}$ it needs further explanation, however, as the Court's reasoning tends, like its discussion of purpose, to be conclusory.

A footnote to the Court's reference in Reeves to "considerations of sovereignty" cites a lower court case for the proposition that "“ad hoc' inquiry into the burdening of interstate commerce would "unduly inter-

70. Reeves, Inc. v. Stake, 447 U.S. 429, 438-39 (1980) (quoting Heim v. McCall, 239 U.S. 175, 191 (1915) and United States v. Colgate \& Co., 250 U.S. 300, 307 (1919)) (footnotes omitted).

71. Id. at 438.

72. See infra Part IV. 
fere with state proprietary functions if not bring them to a standstill.",73 Such an inquiry, however, occurs only when the state favors its own citizens. Whether it is appropriate for the state to favor its own citizens in proprietary functions is the question at the base of the market participation doctrine. Interference is undue only if it disturbs legitimate activity of the state. ${ }^{74}$ If a preference for one's own citizens is inappropriate, then the problem of discouraging legitimate activity centers on the failure to offer clear guidelines for judgment. Sharp boundaries for distinguishing legitimate and illegitimate state acts can resolve that problem. Rather than constituting a principled objection to dormant Commerce Clause review, the "sovereignty" argument would appear to be a critique regarding the proper statement of principle.

The Court's footnote ten in Reeves also mentioned that some regulations of "integral operations in areas of traditional governmental functions" might not be subject to Congressional regulation under the commerce power, ${ }^{75}$ relying on the National League of Cities decision that it later rejected in Garcia. $^{76}$ While it is obvious that Congress cannot invalidate state laws by silence that it cannot invalidate by enacting a statute, that fact does not explain why the dormant Commerce Clause should not apply to state behavior that the federal government can prohibit. Justice Powell, dissenting in Reeves, argued that the market participant exception should only apply to the state when it performed traditional state functions. ${ }^{77}$ Such a rule would have been consistent with the National League of Cities decision, but the Reeves majority rejected the traditional function theory as the basis for the market participant doctrine by applying the market participant doctrine to cement production, which is not a traditional function of government. ${ }^{78}$ Because the Court was willing to shelter protectionist behavior that Congress could prohibit even under the overruled National League of Cities doctrine, the footnote in Reeves offers little justification for the market participant doctrine.

73. Reeves, 447 U.S. at 438 n.10 (citing Am. Yearbook Co. v. Askew, 339 F. Supp. 719, 725 (M.D. Fla. 1972)).

74. See Fair Assessment in Real Estate Ass'n v. McNary, 454 U.S. 100, 112 (1981).

75. Reeves, 447 U.S. at 438 n. 10.

76. Nat'l League of Cities v. Usery, 426 U.S. 833 (1976), overruled by Garcia v. San Antonio Metro. Transit Auth., 469 U.S. 528 (1985).

77. Reeves, 447 U.S. at 451 (Powell, J., dissenting). See also Dan T. Coenen, Untangling the Market Participant Exemption to the Dormant Commerce Clause, $88 \mathrm{MiCH}$. L. REv. 395, 406-09 (1989) [hereinafter Untangling the Exemption] (critiquing the traditional function theory of Powell).

78. Reeves, 447 U.S. at $435-36 \mathrm{nn} .7-8$. 
Furthermore, federal power over the states expanded when the Court overruled National League of Cities. ${ }^{79}$ Even though the Court has found that the federal Commerce Clause power is limited ${ }^{80}$ and that Congress cannot directly compel a state to enact a law ${ }^{81}$ or conscript state officials to enforce and administer a federal program, ${ }^{82}$ it has not yet reversed Garcia. Congress has power to regulate states under the Commerce Clause as long as the federal law does not require the state to enact specific laws or perform federal functions. ${ }^{83}$ When the state is participating in the interstate market for goods or services, whether by traditional operations or in a proprietary fashion, Congress has power to regulate it. ${ }^{84}$ Thus, none of the limits on congressional power can justify the market participant exception to the dormant Commerce Clause.

The Court concluded its footnote on considerations of sovereignty by saying that "States may fairly claim some measure of a sovereign interest in retaining freedom to decide how, with whom, and for whose benefit to deal, ${ }^{, 85}$ but the Court has never found that this interest overrides Congressional decisions to the contrary. Consequently, the considerations of sovereignty behind the market participant doctrine were either rooted in doctrine now repudiated or need further explanation.

Professor Dan T. Coenen, who served as Justice Blackmun's law clerk when the Justice wrote Reeves, has written a series of fine articles analyzing the problems raised when a state favors its residents through subsidies, taxes, purchases and sales. ${ }^{86}$ Coenen has argued that the market participant doctrine is justified by several different considerations and that its application should reflect a balancing of those factors. ${ }^{87}$ Coenen's articles also provide additional possible explanations for the

79. See Garcia, 469 U.S. 528 (overruling Nat'l League of Cities, 426 U.S. 833, and holding that Congress may regulate traditional government functions of states pursuant to the Commerce Clause).

80. See United States v. Lopez, 514 U.S. 549, 566-68 (1995); United States v. Morrison, 529 U.S. 598, 607-08 (2000).

81. New York v. United States, 505 U.S. 144, 149 (1992).

82. Printz v. United States, 521 U.S. 898, 935 (1997).

83. Reno v. Condon, 528 U.S. 141, 151 (2000).

84. See Garcia at $545-47$.

85. Reeves, Inc. v. Stake, 447 U.S. 429,438 n. 10 (1980).

86. Dan T. Coenen, Business Subsidies and the Dormant Commerce Clause, 107 Y ALE L.J. 965 (1998) [hereinafter Business Subsidies]; Dan T. Coenen, State User Fees and the Dormant Commerce Clause, 50 VAND. L. REV. 795 (1997) [hereinafter State User Fees]; Dan T. Coenen, The Impact of Garcia on the Market Participant Exception to the Dormant Commerce Clause, 1995 U. ILL. L. REV. 727 (1995) [hereinafter The Impact of Garcia]; Coenen, Untangling the Exemption, supra note 77 .

87. In Untangling the Exemption, before offering his own analysis, Coenen examines the theories of others (Justices Powell and Brennan, and Professors Varat, Tribe, Regan, and Gergen) in a convincing critique. Coenen, supra note 77 , at $408-19$. 
Court's decision. ${ }^{88}$ Coenen has suggested that Justice Blackmun's mention in Reeves of "considerations of state sovereignty," and the footnote's reference to the state interest in the freedom to decide with whom to deal, referred to values of federalism. ${ }^{89}$

One aspect of federalism is the autonomy of the state. Professor Coenen has argued that restrictions on state market decisions are a greater intrusion on state autonomy than are limits on its regulatory power. ${ }^{90}$ There is an intrinsic appeal to the notion that decisions about one's own conduct are core to autonomy in a manner quite different from decisions about the behavior of others. States, however, are not individuals; they are an abstraction. The "autonomy" of an abstract body does not correlate directly with individual autonomy. Regulation is a basic function of the state, and interference with state regulations affects the relationship between the state and the people who constitute it. ${ }^{91}$ It makes a difference whether the state is deciding with whom it will deal as opposed to deciding with whom others are permitted to deal, but references to "autonomy" are not a sufficient explanation for that difference. ${ }^{92}$

Coenen points out that the Court differentiates between state policy, which may be enjoined, and state resources, which are protected from monetary damage awards. ${ }^{93}$ This remedial aspect illuminates the Court's reluctance to act against the state as market participant, but Coenen does not develop his thought in this direction. Instead, he stresses the distor-

88. Professor Coenen offers five principal justifications for the market participant doctrine, justifications that largely complement those in the Reeves opinion:

First, as a general matter, it is fair and consistent with broadly shared conceptions of property to let state governments favor state residents when selecting the recipients of the state's own largess. Second, the values of federalism suggest a special need to avoid interference with state autonomy in this area. Third, marketplace preferences for local concerns in general pose less of a danger to Commerce Clause values than do those discriminatory regulations and taxes that engendered recognition of the dormant Commerce Clause principle. Fourth, formal considerations-emanating from constitutional text and history - suggest that states should have a freer hand when dealing in the market than when regulating others' efforts at free trade. And fifth, institutional considerations counsel heightened caution in applying the dormant Commerce Clause to market-participant cases.

Coenen, The Impact of Garcia, supra note 86, at 744.

89. Coenen, supra note 77 , at 426.

90. Id. at 427.

91. See Matthew Adler \& Seth Kreimer, The New Etiquette of Federalism: New York, Printz, and Yeskey, 1998 SUP. CT. REV. 71, 95-100 (arguing that there is no distinction in impact on federalism between preemption and commandeering of state officials because they equally displace state choices).

92. See infra Part IV.

93. Coenen, supra note 77 , at 428 . Eleventh Amendment sovereign immunity, although rarely invoked directly, is a significant factor in the analysis of the market participant doctrine. See infra text accompanying notes $164-71$. 
tion of state decision-making that would result from application of the dormant Commerce Clause to state sales and purchases. ${ }^{94}$

Coenen has argued that a rule that permits subsidies while denying marketplace favoritism would distort state choices toward subsidies instead of market action. ${ }^{95}$ According to Coenen, two key goals of federalism are the encouragement of state experimentation and government responsiveness to local needs. ${ }^{96}$ Forbidding preferences in market transactions runs counter to these goals. ${ }^{97}$ However, all restrictions on state laws are likely to have that effect. The issue is whether other policies outweigh the freedom to make such choices. For example, the dormant Commerce Clause already restricts a state from using its regulatory power to advantage its citizens over others in interstate commerce, ${ }^{98}$ and therefore compels the state to use market power rather than regulatory power to aid its citizens. Thus, the distortion-of-state-decision-making argument justifies the market participant doctrine only if it is legitimate for a state to decide to enhance its companies by giving them a preference in its market decisions. Instead of providing strong support for the market participant doctrine, the distortion argument merely rephrases the issue.

In sum, the Court in Reeves did not spend much effort discussing how the concern for state sovereignty distinguished the invalidation of state regulations from the invalidation of state market decisions. This may be why the court has had such difficulty in its application of the doctrine.

\section{The Role of the State as Guardian of its People}

The Court in Reeves found support for the market participant doctrine in "the role of the state as guardian and trustee for its people." pointed to the power of the state to determine the services and functions that the public welfare requires. ${ }^{100}$ While the state has an interest in protecting its citizens through all its laws and regulations, that fact alone does not permit the state to enact laws discriminating against nonresidents.

The Court in Reeves cited several cases that indicated in dictum that the state had power to retain a food supply for itself, but such dicta is at

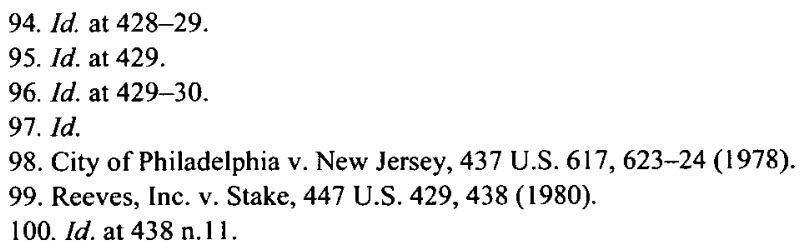


least questionable. ${ }^{101}$ Coenen, citing Bushrod Washington, notes that the state is an abstract entity consisting of the people who have banded together. ${ }^{102}$ Thus, resources belonging to the state belong to the group who constitute it. Therefore, the state should be able to limit the distribution of these resources to members of the group. ${ }^{103}$ However, the resources in question are largely monetary, raised not only from the state's own citizens but from taxes on the citizens of other states as well. ${ }^{104}$ The issue is whether the constructive "ownership" of resources by the state justifies the market participant doctrine despite its impact on interstate commerce.

The role of the state as "guardian and trustee" of its people does not prevent Congress from using the Commerce Clause to regulate commercial dealings of the state that harm interstate commerce. ${ }^{105}$ When the dissenters in Reeves urged the Court to invalidate South Dakota's preference because it was an intentional interference with interstate commerce and a return to economic protectionism, ${ }^{106}$ they were not calling for action beyond that contained in the commerce power of Congress. The dissenters argued that, because the Commerce Clause was anti-protectionist in purpose, the preference was unconstitutional even in the absence of Congressional action. ${ }^{107}$

The Court in Reeves responded to accusations of "protectionism" by claiming that the policies were protectionist only in the sense that they "limit benefits generated by a state program to those who fund the state treasury and whom the State was created to serve." ${ }^{108}$ This comment suggests that retention of benefits for those who fund the benefits was a core element in the notion of the state as guardian of the people. This is the kernel of the "reap what you sow" analysis of several commentators. ${ }^{109}$

Coenen elaborated on the Court's view of the role of the state when he argued that the market participant doctrine is also justified by the fair-

101. Id. The Court distinguished cement from natural resources or other resources that could not be obtained elsewhere, recognizing that an embargo of commodities or resources for the exclusive use of residents would violate a core purpose of the Commerce Clause. Id. at 443.

102. Coenen, supra note 77, at 422 n.175 (citing Corfield v. Coryell, 6 F. Cas. 546, 552 (C.C.E.D. Pa. 1823) (Washington, J.)).

103. Id.

104. See id. at 425.

105. Garcia v. San Antonio Metro. Transit Auth., 469 U.S. 528, 545-47 (1985).

106. Reeves, 447 U.S. at 452-53 (Powell, J., joined by Brennan, White, and Stevens, JJ., dissenting)

107. Id. at $447-50$.

108. Id. at 442.

109. See Coenen, The Impact of Garcia, supra note 86, at 746; see generally Jonathan Varat, State "Citizenship" and Interstate Equality, 48 U. CHI. L. REV. 487 (1981). 
ness of directing state benefits to state residents. ${ }^{110}$ Residents are subject to the jurisdiction of the state and may be taxed on their income and property regardless of its source; accordingly, they contribute significantly more to the state treasury than do nonresidents, who are taxed only on activities and property within the state. ${ }^{111}$ For that reason the state may favor its residents in the disbursement of monies from the state treasury. ${ }^{112}$ With respect to a variety of benefits-e.g., public education-this is an excellent justification. ${ }^{113}$ It is a major pillar for upholding state subsidies to local businesses, despite the prohibition on disparate taxes. ${ }^{114}$ Several of Coenen's articles address the appropriate standard to apply for business subsidies, where the state is making grants rather than participating in the market. ${ }^{115}$ Coenen contends that state subsidization of local interests should largely be permitted, subject to a multi-factor test. ${ }^{116} \mathrm{He}$ argues further that if such an analysis of the dormant Commerce Clause is correct, it is applicable when the state acts as market participant rather than as a subsidizer; ${ }^{17}$ however, the notion of reaping where you sow has much less to recommend it when considering the state's preferences as a market participant. ${ }^{118}$

Local preferences in buying or selling goods or services permit the state to leverage its resources in diverting business towards the in-state company. The state revenues that helped create the government good or service paid for by a purchaser are like bond revenues paid off by the revenues from sales: the taxpayers get some or all of their money back in the form of goods or services, so the original participation through financing does not justify the regulation that limits sale to residents. If the state buys or sells goods or services at the market price, the nonresident provides value for the money spent. Purchase by the state with state revenues results in the state obtaining a good or service, so purchases from out-of-state sellers do not reduce the net value to the state. ${ }^{119}$ The

110. Coenen, supra note 77 , at $420-26$.

111. See id. at 425.

112. See id. at 420-26; Coenen, Business Subsidies, supra note 86, at 983-84.

113. Residence is a good proxy for the creation of public goods. Education benefits both the children of the residents and those who will benefit from the existence of an educated population in the state, but the state would be discouraged from providing the benefit, especially a high quality benefit, if it must be afforded to nonresidents.

114. See Coenen, Business Subsidies, supra note 86, at 1030-33.

115. Id. at 1030-54; Coenen, supra note 77, at 473-79.

116. Id.

117. Coenen, Business Subsidies, supra note 86, at 1031.

118. See David Bogen, Privileges and Immunities: A Reference Guide to the United STATES CONSTITUTION 83-85 (2003).

119. The state might achieve a greater benefit for its citizens by contracting in-state because the contracting party would be likely to spend that money within the state, but that is true as well of 
nonresident is not a parasite leeching off the revenues of the state, and his access to the state market might not affect whether the state enters it.

To the extent that preferences result in prices slightly different from the market, the economic cost of preferences operates as an indirect subsidy to local business. But should the tail of a small subsidy wag the dog of a prohibition on interstate government transactions? The fairness of state subsidies is more apparent than is the fairness of limiting the market for government sales and purchases to state residents. The justification of reaping what one sows simply does not work as well for transactions by the government in the general marketplace.

\section{The Trader's Right to Decide with Whom to Deal}

The majority in Reeves suggested that a state should be free to discriminate in its actions as a participant in the market because other traders enjoy this freedom. ${ }^{120}$ Although a trader may traditionally have the right to decide with whom to deal, Congress certainly has power under the Commerce Clause to restrict that freedom and, for example, to prohibit discrimination by private companies based on race or sex. ${ }^{121}$ Thus, there is no constitutional recognition of any right to decide with whom to deal-it is a matter of grace with respect to private traders. This argument is a weak prop for finding that states have a right to decide with whom to deal.

The state is quite different from the private trader, and the failure of Congress to regulate the private trader is barely relevant. In the absence of legislation, private traders are free to make decisions that a state cannot. For example, the Constitution forbids certain decisions by the state based on race, ${ }^{122}$ and conditioning commercial dealings on speech supporting the government would raise constitutional free speech concerns. ${ }^{123}$ Thus, private traders' freedom of choice is not inconsistent with an implied limit on state discrimination against companies from other states.

Further, there is no need to protect against discrimination in favor of persons located in the same state because the private traders' selfinterest will lead them to disregard location unless it affects price or

regulations that limit interstate transactions. It is not that the contract is a "zero sum" transaction, but that the additional benefits obtained for citizens are not justified by the taxes they paid.

120. Reeves, Inc. v. Stake, 447 U.S. 429, 438 (1980).

121. Heart of Atlanta Motel v. United States, 379 U.S. 241, 258-59 (1964); Katzenbach v. McClung, 379 U.S. 294, 301-04 (1964).

122. U.S. CONST. amend. XIV, $\S 1$.

123. U.S. CONST. amend I. 
quality. ${ }^{124}$ That is not true of the state, which may favor local industries for political rather than economic reasons.

Coenen explains Reeves's discussion of the trader rationale as grounded in the proposition that preferences within the market have a lesser degree of impact on the values of the Commerce Clause than do regulations of the market. ${ }^{125}$ Allowing the state to engage in resident preferences in its decisions does not pose as significant a threat to the Union as allowing discriminatory regulation. ${ }^{126}$ Both scope and economic impact will limit the degree of harm a market participant exemption would cause to Commerce Clause concerns. ${ }^{127}$ Because the state as market participant affects only a portion of the total state market, it will not have as great a distorting effect against interstate commerce. ${ }^{128}$ Further, because the state as a trader will be discouraged from preferences by its costliness, other states are more likely to find its preference fair and thus resent it less. ${ }^{129}$

An argument based on lessened impact suggests a balancing test that favors state preferences in the market more frequently than in regulation, but does not in itself justify an exemption from the balancing test. Where the state creates the market, as in Hughes, it is hard to distinguish the impact of a preference from a regulation. Even where the state merely dominates, as in Reeves, the state's preferences may be nearly as effective as regulation in impacting the total state market because competitors in the market are distant. Furthermore, the costs of local favoritism in the market are much less obvious than those of subsidies. They show up only when outsiders bid, and while they are apparent to the state officials involved in the selection process, they are unlikely to be noted in the balance sheet or the budget and are not readily apparent to the voters and the legislature. ${ }^{130}$

Coenen argues that the freedom of the private trader creates an assumption that participants in the market are not restricted. ${ }^{131}$ However, there is no assumption that the state can discriminate by race or gender in

124. Coenen, supra note 77 , at $431-32$.

125. Id. at 430 .

126. Id. at 434.

127. See id. at 432-35.

128. The state may affect the entire market as the sole seller or buyer of particular goods, but Coenen argues that the state is still participating in the market to make gains through trade even if those gains include benefiting its residents. Thus, he argues that the subversion of the national market is not as apparent as when taxes or regulations are imposed. Id. at 432-33.

129. Id. at 434-35.

130. See Coenen, Business Subsidies, supra note 86 , at $986-87$.

131. Coenen, supra note 77, at 430 n.219 (citing New Orleans S.S. Assoc. v. Plaquemines Port, Harbor \& Terminal Dist., 874 F.2d 1018, 1021 (5th Cir. 1989) as an example of a court expressing such an assumption). 
the marketplace, even if the private trader can; the linguistic assumption is thus a weak reed.

Another linguistic argument focuses on the Commerce Clause vesting Congress with power to "regulate."132 The negative implication of that power is that states cannot regulate, but can act in other ways that affect commerce but are not generally considered regulation. ${ }^{133}$ This justification for the market participant doctrine is not as persuasive as it might have been nearly two centuries ago. The Court no longer understands the Commerce Clause to bar all state regulation: instead, the dormant Commerce Clause only affects discriminatory regulations and "undue burdens." 134 These distinctions are based on policy assumptions about the purpose of the Clause-assumptions that could apply to any state action that affects interstate commerce. ${ }^{135}$ The language of the Clause supports the market participant doctrine, but certainly does not require it. It is the policy arguments that drive the doctrine.

\section{Evenhandedness in Burdens on Trade}

The Court in Reeves pointed out that states are subject to the same burdens as private traders, and suggested that they should be similarly free from restrictions that do not apply to others in the market. ${ }^{136}$ However, states are often free of burdens that would apply to private traders. For example, the commerce power does not enable Congress to override state sovereign immunity under the Eleventh Amendment. ${ }^{137}$ Thus, states may have immunity from damage suits brought by individuals that private defendants do not. Similarly, federal regulations may not apply to states without a plain statement that Congress intends them to apply. ${ }^{138}$

132. Coenen, The Impact of Garcia, supra note 86 , at $740-42$.

133. Id. at 740-41 (footnotes omitted).

The Constitution, after all, vests Congress with power to "regulate" interstate commerce. As a result, if the Commerce Clause carries with it any "negative implications," those implications must teach that states cannot "regulate" in particular ways. In keeping with common usage, the Court has found that a "regulation" of commerce simply is not present-and thus cannot be made unlawful by the Commerce Clause-when a state, for exId. ample, buys office furniture or sells cement.

134. See United States v. Lopez, 514 U.S. 549, 579-80 (1995).

135. See discussion supra Part II.

136. Reeves, Inc. v. Stake, 447 U.S. 429, 439 (1980).

137. Seminole Tribe of Fla. v. Florida, 517 U.S. 44, 47 (1996); Alden v. Maine, 527 U.S. 706, 754 (1999); Kimel v. Fla. Bd. of Regents, 528 U.S. 62, 78-79 (2000).

138. See Gregory v. Asheroft, 50I U.S. 452, 467 (1991) (finding ADEA inapplicable to a state judge required by state law to retire at seventy in the absence of a clear statement of intent to make law applicable to state). The Court subsequently held that Congress could not confer a private right of action against the state under the ADEA because it was barred by state sovereign immunity. Kimel, 528 U.S. at 91. But cf. Tennessee v. Lane, 541 U.S. 509, 517-20 (2004) (finding the Americans 
The flip side is that states differ significantly from private traders and are normally subject to restrictions, particularly constitutional restrictions, that do not apply to private parties. ${ }^{139}$

\section{Difficulty of Commerce Clause Balancing}

The Court in Reeves asserted that the application of traditional Commerce Clause doctrine to proprietary state actions would often be difficult, and that it would therefore be better for Congress to adjust the interests. ${ }^{140}$ Of course, dormant Commerce Clause opponents have suggested deference to Congress with respect to all applications of the doctrine. ${ }^{141}$ The Court, however, has still invalidated discriminatory state laws when the state is a market regulator. ${ }^{142}$

The test of discrimination against interstate commerce or undue burden may be difficult, but the Court has not shrunk from its application. Facially discriminatory laws require a high degree of justification, ${ }^{143}$ and the balancing test for laws that do not discriminate against interstate commerce involves analyzing the benefit to local interests and the burden on interstate commerce. ${ }^{144}$ The state may be able to satisfy a balancing test more often when acting as a market participant than as a regulator because the burden it imposes on interstate commerce is likely to be less, and there will be less distortion of the market. ${ }^{145}$ Critics complain that the balancing test is inappropriate at any time because it is subjective and difficult to apply. ${ }^{146}$ But if the Court believes that it has a responsibility to vindicate the purposes of the Commerce Clause through that test, it should operate in much the same way for market participant

with Disabilities Act (ADA) applicable to state failure to provide facilities for handicapped entrance to courthouse).

139. Note Coenen's dismissal of this justification. Coenen, supra note 77 , at $430-32$.

140. Reeves, 447 U.S. at 439.

141. Camps Newfound/Owatonna, Inc. v. Town of Harrison, 520 U.S. 564, 610, 620 (1997)

(Thomas, J., joined by Scalia, J., and Rehnquist, C.J., dissenting).

The negative Commerce Clause has no basis in the text of the Constitution, makes little sense, and has proved virtually unworkable in application ... . [T] [he Court should confine itself to interpreting the text of the Constitution, which itself seems to prohibit in plain terms certain of the more egregious state taxes on interstate commerce described above, and leaves to Congress the policy choices necessary for any further regulation of interstate commerce.

Id. See generally Eule, supra note 42.

142. "Although Congress unquestionably has the power to repudiate or substantially modify that course of adjudication, it has not done so." Camps Newfound/Owatonna, 520 U.S. at 572.

143. "If a restriction on commerce is discriminatory, it is virtually per se invalid." Or. Waste

Sys., Inc. v. Dep't of Envtl. Quality, 511 U.S. 93, 99 (1994).

144. Pike v. Bruce Church, Inc. 397 U.S. 137, 142 (1970).

145. See Coenen, supra note 77, at 432-33.

146. See generally Regan, supra note 42, at 1101-08; Eule, supra note 42, at 439-43. 
cases; application would likely prove more difficult to manage only in initial cases. If the Court finds that the policy of the Commerce Clause decries protectionism, it would seem logical for it to act rather than allow that purpose to be frustrated. The difficulty of the decision does not suggest a shift in the responsibility for it. Congress always possesses the ultimate power to decide, ${ }^{147}$ and the Court should always defer to its action.

Coenen argues that market decisions introduce concerns not usually present in dormant Commerce Clause balancing that make it difficult to give appropriate weights. ${ }^{148}$ Thus, the complexity presented by adding together the other justifications for exemption suggests a more rigid rule. But when is a rigid rule appropriate? Coenen's analysis supports the specific decisions made by the Court, but only by a multi-factor approach that produces balancing rather than the rigid rule suggested by the difficulties of balancing; the resulting doctrine may be sensitive to a variety of concerns, but it is far from clear. ${ }^{149}$

In short, while the Court has been clear that the state is not subject to the dormant Commerce Clause when it acts as a market participant, its rationale has tended to be conclusory. The assertion that the Commerce Clause was not directed at this type of behavior meets the dissent's equally conclusory assertion that it was. State sovereignty considerations do not preclude federal restrictions on state behavior that interferes with the interstate market. The power of the state to make policy choices is not unlimited, and its role as guardian of its citizens does not permit it to discriminate in commercial regulation. Private trader comparisons do not survive scrutiny. Finally, the complexity of dormant Commerce Clause analysis has never prevented its application.

If Congress has the power to prohibit economic protectionism even when the state acts as a market participant, why should the dormant Commerce Clause not prohibit it in the absence of affirmative congressional support? ${ }^{150}$ Academic critics of the market participant doctrine

147. See U.S. CoNST., art. I, $\S 8$, cl. 3.

148. Coenen, supra note 77 , at $440-41$.

149. Coenen establishes the following framework for analysis of market participant issues:

(1) whether the program reflects an effort of local citizens to reap where they have sown;

(2) whether invalidation of the program is consonant with the underlying values of federalism, including in particular the values of local experimentation and optimal responsiveness to local concerns;

(3) to what extent the program threatens the underlying Commerce Clause values of a free market and unified nation; and

(4) whether the state bears the appearance of "participating in," rather than "regulating," the market.

Id.

150. Harvard Law Review Association, Market Participant Immunity, 97 HARV. L. Rev. 70, 72 n.26 (1983) (internal citations omitted). 
proffer economic analysis and press the Court to invalidate restrictions when they find them insufficiently justified. ${ }^{151}$

The problem with balancing has always been that the values used in the weighing are subjective. The market participant doctrine can be made consistent and clear, however, by expanding on the values of federalism and sovereignty to draw the line between participant and regulator, and by utilizing the other factors as subsidiary support for the practical implementation of the dichotomy.

\section{IV. "CONSIDERATIONS OF SOVEREIGNTY": THE Clear STATEMENT Rule}

One of the great innovations of the United States Constitution was its avoidance of the conflict of sovereigns that was produced when the national government ordered the state to take action: ${ }^{152}$ by conferring power on the federal government to regulate individuals directly, the Constitution enabled the federal government to achieve its objectives without directly confronting the state. ${ }^{153}$ Alexander Hamilton was concerned that dependence on the state to carry out national policies would render the national government dysfunctional: the states were too powerful, and the national government too weak, for the federal government to compel state obedience. ${ }^{154}$ The federal government today has grown much more powerful at the expense of the states, but direct regulation

\footnotetext{
The Commerce Clause purpose theory is inadequate because Commerce Clause jurisprudence has historically been concerned not with the form of government action, but with the effect of such action on interstate commerce and the threat of "economic balkanization." The sovereignty theory does not explain why a state should enjoy immunity when it acts as a market participant but not when it acts as a regulator. The political deference theory may justify dispensing with the dormant Commerce Clause analysis altogether, but it has little force as a reason for the limited exception of market participant immunity, The market discipline theory is unconvincing because the government differs from other market participants: it has access to the public fisc, and its decisions, even with respect to market participation, rarely resemble those of the rational, profit-maximizing economic actor that the market-disciplining devices contemplate.
}

Id.

151. See, e.g., Thomas K. Anson \& P.M. Schenkkan, Federalism, the Dormant Commerce Clause, and State-Owned Resources, 59 TEx. L. REv. 71 (1980); Mark P. Gergen, The Selfish State and the Market, 66 TEX. L. REV. 1097, 1107 (1988).

152. THE FEDERALIST No. 16 (Alexander Hamilton) (explaining the danger of ordering the state governments to act to produce a federally desired result).

153. Id. Hamilton pointed out the difference between noncompliance and active resistance, arguing that direct legislation over individuals enables the federal government to accomplish its purposes unless the state actively intervenes.

154. Id. 
still avoids the friction created by attempting to compel the states to carry out national policies. ${ }^{155}$

Both state and federal government are sovereign with respect to individuals, but the federal rule takes precedence by virtue of the Supremacy Clause. ${ }^{156}$ With respect to individuals, the state is free to regulate as it will; its autonomy to act on its own behalf is unaffected by the invalidation of regulations. Indeed, any attempt to compel the state to legislate, rather than simply invalidating its unconstitutional legislation, is an unconstitutional intrusion on state sovereignty. ${ }^{157}$ Dual sovereignty issues arise in suits between individuals or suits by the state against an individual in which the court may refuse to give effect to state laws that conflict with federal law. In this manner, the enforcement of federal law is essentially passive: it does not result in any order against the state. As long as the state courts abide by the decisions of the Supreme Court, federal supremacy is accomplished without the need to order state officials to act, and the result is the same regardless of whether the court invalidates the state law pursuant to a federal statute or to the dormant Commerce Clause.

The situation is considerably different when the state discriminates in favor of its citizens in its purchase or sale of goods or services. A prohibition on state discrimination in its market decisions is not a shield for someone violating the policy, but rather is a sword directing the state official to behave consistently with federal policy. This prohibition creates the risk that state officials might disobey and force the unseemly spectacle of federal force being used against them. In the extreme, it leads to the jailing of state officials, which precludes them from functioning in their governmental role. ${ }^{158}$

If a state official obeys a court's order, the order blurs the line of responsibility between the state official and the people of the state: is the official acting because it is appropriate policy, or because the courts

155. Federal-state cooperation may provide flexibility and local knowledge, and thus may be more efficient than federal command. The federal government has also allowed states to enforce their own law in place of federal enforcement in many areas where the state law meets federal standards, but the use of the carrot or the stick to coordinate federal-state relationships remains a different matter than directly ordering the state to act in a specific manner.

156. U.S. CONST. art. VI.

157. See New York v. United States, 505 U.S. 144, 166 (1992) ("The allocation of power contained in the Commerce Clause, for example, authorizes Congress to regulate interstate commerce directly; it does not authorize Congress to regulate state governments' regulation of interstate commerce.").

158. Of course, state officials may disobey judicial orders that enjoin them from carrying out laws or regulations that are unconstitutional, but official behavior in violation of the courts is such a flagrant violation of due process in its impact on the individual that it would be more rare, and most state citizens would view sanctioning such conduct as more appropriate. 
command it? Application of the dormant Commerce Clause to the state's purchase and sale decisions would undermine the autonomy of state governments. ${ }^{159}$

That is what the court meant in Reeves when it said that "considerations of sovereignty" supported the market participant doctrine and its analysis of the purpose of the Commerce Clause. ${ }^{160}$ Invalidating state regulations of the private sector leaves parties free to exercise their autonomy; invalidating state preferences in contracting deprives the state of its autonomy. It does not simply declare that a state regulation is superseded; rather, it directly commands the state to act in a specific manner. After Garcia, the federal government certainly has power to do this ${ }^{161}$ - the question is whether it has done so.

A federal law that orders the state to act in a specific manner creates a potential confrontation, as it may be necessary or advisable for the federal government to command the state in some respect, but the Court has demanded a clear statement by Congress before it will find that an enactment applies to the state. ${ }^{162}$ The Court assumes that a general regulation does not apply to the state unless Congress specifically states that it

159. But see Adler \& Kreimer, supra note 91, at 143 (arguing that there is no distinction in impact on federalism between preemption and commandeering of state officials because they equally displace state choices). Of course, all limits on state authority restrict choices and undermine autonomy, but a direction with respect to the state's own governance process does so far more significantly. First, a prohibition on particular behavior is likely to leave a greater range of choice for the state to exercise its autonomy than is a command to engage in particular actions. Second, state action raises issues of authority and legitimacy that inaction does not. Where the source for the law is federal rather than state, the political function of the state as representative of its citizens is undermined.

160. Reeves, Inc. v. Stake, 447 U.S. 429, 438 (1980).

161. Garcia v. San Antonio Metro. Transit Auth., 469 U.S. 528, 555-56 (1985) (finding municipal transit authority subject to federal regulation of wages and hours of workers). See also Reno v. Condon, 528 U.S. 141, 148-51 (2000) (unanimously upholding the prohibition on sale of personal data by states).

162. The Court applied a clear statement rule to determine whether a statute applied to the sovereign that enacted it, Dollar Sav. Bank v. United States, 86 U.S. 227, 239 (1873); Guar. Title \& Trust v. Title Guar. \& Safety, 224 U.S. 152, 155 (1912), and found it to be consistent with a tradition of construing statutes to avoid conflict with the Constitution. Crowell v. Benson, 285 U.S. 22, 62 (1932). However, the Court did not initially require a clear statement in order for federal statutes to apply to state operations. See New York, 326 U.S. at 584-86 (Rutledge, J. concurring). The Court later began to construe federal statutes as failing to overcome a state's Eleventh Amendment immunity from private suit absent an express congressional statement. See Employees of Dept. of Pub. Health \& Welfare v. Dept. of Pub. Health of Mo., 411 U.S. 279, 284-85 (1971). This principle expanded to the general proposition that a clear statement was required to displace traditional federalstate relationships. Gregory v. Ashcroft, 501 U.S. 452, 460 (1991). The clear statement rule in its strongest form is controversial. See William Eskridge, Jr. \& Phillip Frickey, Quasi-Constitutional Law: Clear Statement Rules as Constitutional Lawmaking, 45 VAND. L. REV. 593, 629-40 (1992) (opposing the use of the clear statement rule) and Todd Pettys, Competing for the People's Affection: Federalism's Forgotten Marketplace, 56 VAND. L. REV. 329, 383-84 (2003) (supporting the clear statement rule's use to further federalism). 
does. ${ }^{163}$ With respect to enforcement of the dormant Commerce Clause, there is by definition no such clear statement because there is no statement from Congress whatsoever. Thus, the dormant Commerce Clause doctrine cannot be used to forbid a state from making any particular purchase or sale decision. This is the core of the market participant doctrine. ${ }^{164}$

Sensitivity to a state's autonomy is also reflected in the principle of sovereign immunity. When the Supreme Court allowed a person to sue a state for breach of contract in federal court, ${ }^{165}$ it provoked an outcry that led to the adoption of the Eleventh Amendment, which provides: "The Judicial power of the United States shall not be construed to extend to any suit in law or equity, commenced or prosecuted against one of these United States by Citizens of another State, or by Citizens or Subjects of any Foreign State." 166 The Supreme Court has found that the Eleventh Amendment reflects the principle of sovereign immunity that existed when the Constitution was adopted, and has given effect to that principle even where the language of the Amendment does not directly apply. ${ }^{167}$ The Court has been concerned with the danger such suits pose to a state's allocation of its resources. ${ }^{168}$ If individuals can get damages from the government, the payment comes from the resources of society as a whole, though most societal members played no part in causing the harm. The government as lawmaker determines to what degree the law will apply to it, ${ }^{169}$ and balances compensation for harms it has caused against other uses of its resources. The federal government is a separate source of lawmaking power, but the Court has found that state control over revenues and payments remains an important value to be protected

163. Gregory v. Ashcroft, 501 U.S. 452, 460, 467 (1991); Will v. Mich. Dep't of State Police, 491 U.S. 58, 65 (1989); Atascadero State Hosp. v. Scanlon, 473 U.S. 234, 242 (1985).

164. If this principle is correct, it further supports the difference in review of state taxes versus state subsidies. The dormant Commerce Clause is a defense for the person upon whom a discriminatory tax is levied, and discriminatory taxes will be invalidated under the dormant Commerce Clause. See West Lynn Creamery, Inc. v. Healy, 512 U.S. 186, 192-94 (1994). On the other hand, the party challenging a discriminatory subsidy would be a competitor seeking an order requiring the state to either stop subsidizing altogether or provide a subsidy to the challenger. Discriminatory subsidies are normally not a problem unless they are linked to a tax so as to operate in practice as a discriminatory tax. West Lynn Creamery, 512 U.S. at 199. See also Coenen, Business Subsidies, supra note 86, at 977-78.

165. Chisholm v. Georgia, 2 U.S. (2 Dall.) 419 (1793).

166. U.S. CONST. amend. XI.

167. Hans v. Louisiana, 134 U.S. 1, 10-15 (1890) (holding that sovereign immunity bars suit against a state by one of its own citizens even though Eleventh Amendment by its terms applies only to citizens of other states); Alden v. Maine, 527 U.S. 706, 712-13 (1999) (holding that sovereign immunity bars Congress from giving private right of action under Commerce Clause in state courts).

168. See Employees of Dept. of Pub. Health \& Welfare v. Dept. of Pub. Health of Mo., 411 U.S. $279,284-85$ (1971).

169. See Hans, 134 U.S. at 13. 
even when interpreting the scope of federal power. ${ }^{170}$ Thus, the Court has held that the Commerce Clause does not empower Congress to provide a private cause of action against a state, and does not justify a suit for damages against state officers who have acted in their official capacity. ${ }^{171}$

Persons injured by a state's preference for its own citizens in the market have been deprived of an opportunity to contract. They have been damaged by the loss of profits they might have made or by the failure to get a good or service that is either unattainable or more expensive if purchased elsewhere. If a private company wrongfully refuses to contract and an individual is harmed, that individual can sue for damages or possibly property through specific performance. Private parties cannot sue a state for damages, however, unless the state waives its sovereign immunity ${ }^{172}$ or the injury violates a specific constitutional command. ${ }^{173}$

Sovereign immunity does not preclude federal regulation of state government. ${ }^{174}$ There are limits on sovereign immunity that help keep states within their constitutional bounds and prevent them from frustrating the federal government's policies in areas of federal competence. ${ }^{175}$ The Eleventh Amendment stands as a barrier to recovery from the state for past wrongs, but it does not preclude prospective relief. ${ }^{176}$ Thus, litigants challenging state preference laws seek a declaratory judgment or injunctive relief with respect to contracts the state may enter in the future. The order is sought against the state officials responsible for contracting rather than against the state itself, and the Court has held that injunctive suits to compel state officials to follow federal law are not barred by sovereign immunity. ${ }^{177}$ Thus, a court has power under the Con-

170. Although both suits against state officials in their personal capacity, Scheuer v. Rhodes, 416 U.S. 232, 237-38 (1974), and suits requiring state officials to comply in the future with federal law, Ex parte Young, 209 U.S. 123, 159-60 (1908), are permissible, suit against a state official is barred by the Eleventh Amendment if it requests the state officer to pay funds from the state treasury. Edelman v. Jordan, 415 U.S. 651,677 (1974).

171. Seminole Tribe of Fla. v. Florida, 517 U.S. 44, 47 (1996).

172. Lapides v. Bd. of Regents, 535 U.S. 613, 618-19 (2002) (holding that removal from state to federal court constitutes a waiver as to state law claims for which the state waived its sovereign immunity in state court). See also Alden v. Maine, 527 U.S. 706, 712, 756 (1999) (holding that sovereign immunity bars suit, but private suits against the state are permissible where the state consents and where suits are brought under Fourteenth Amendment enforcement power).

173. Fitzpatrick v. Bitzer, 427 U.S. 445, 456 (1976); see also Alden, 527 U.S. at 756.

174. Prout v. Starr, 188 U.S. 537, 543 (1903).

175. See generally Cent. Va. Cmty. Coll. v. Katz, 126 S. Ct. 990, 1004-05 (2006) (holding that sovereign immunity of states is subordinate to the Bankruptcy Clause); Hans v. Louisiana, 134 U.S. $1(1890)$.

176. Kentucky v. Graham, 473 U.S. 159, 167 n.12 (1985); Edelman v. Jordan, 415 U.S. 65I, 675-77 (1974).

177. Edelman, 415 U.S. at 654; Ex parte Young, 209 U.S. 123, 155-56 (1908). 
stitution to enjoin state officials from discriminating against nonresidents, enforceable by contempt and fines. ${ }^{178}$ Injunctions to preclude state officials from enforcing laws are common in dormant Commerce Clause litigation; however, such injunctions are ancillary to a court's refusal to enforce the state law and do not threaten the state's treasury. Where the injunction does not operate to defend the court but reaches into the operations of state government, a different question is posed: should the intent to allocate money from the state treasury to nonresidents be imputed to Congress when the principle of sovereign immunity would protect that treasury from being used to compensate for past decisions that favored residents? The threat to an interest protected by the doctrine of sovereign immunity suggests the need for an expression by Congress to show that the injunction is necessary.

It might be objected that the state can only act through its agents, and that it controls those agents primarily by rules and regulations-thus many of the market participant cases are actually challenging regulations binding on state or city officials. The public employee is likely to obey the rule, and the litigation will try to compel him to go against the state and violate the rule. In the event that the employee wants to violate the rule, the issue could be raised in a forum that does not directly order the official to act contrary to the state law but is only being requested to protect him-yet even there, the form taken will be an order to preclude the state from firing its own employee.

There is no sovereign immunity for municipalities, but the action of the municipality is considered state action for purposes of the Fourteenth Amendment. ${ }^{179}$ Thus, municipal ordinances must comply with the dormant Commerce Clause. ${ }^{180}$ However, an order based on the dormant Commerce Clause that runs directly against the city in its purchasing and sales interferes with a governmental body's autonomous operations. There is little reason to believe that Congress would permit the state to make preferential market decisions while forbidding the city to do the same. $^{181}$

178. See Hutto v. Finney, 437 U.S. $678,689-90$ n.14 (1978).

179. See, e.g., White v. Mass. Council of Constr. Employers, Inc., 460 U.S. 204 (1983) (analyzing a municipal executive order under dormant Commerce Clause principles).

180. Dean Milk v. City of Madison, 340 U.S. 349, 356 (1951); C \& A Carbone, Inc. v. Town of Clarkstown, 511 U.S. 383, 390 (1994).

181. Several articles have been concerned with the issue of state directives to municipalities that might not want to abide by the preference. Benjamin C. Bair, Note, The Dormant Commerce Clause and State-Mandated Preference Laws in Public Contracting: Developing a More Substantive Application of the Market-Participant Exception, 93 MiCH. L. REV. 2408, 2416-19 (1995); Clark, supra note 66 , at 621 n.37, 624. Like state officials, municipalities derive their authority from state law. The autonomy of the municipality should not override the policy of the state with respect to decisions that the state can make for its agents. 


\section{DOWNSTREAM REGULATION}

That federal courts will not order the state to act in a specific way without a clear statement from Congress is a principle not easily applied when the terms of a state-entered contract are at issue. Contract terms may be invalidated without entering a direct order against the state. When the state is the defendant in litigation over contract terms, it has already contracted, and the order will not impose a choice of contracting parties upon the state. The question is whether that difference is sufficient to support application of the dormant Commerce Clause. The plurality of the Court has applied the dormant Commerce Clause to a contract term that had only a governmental regulatory function, calling it "downstream regulation." ${ }^{182}$ Yet it has upheld a contract term that determined the identity of the person performing work for the state. ${ }^{183}$ Two questions remain-(1) should a common commercial term that limits the contracting party's dealings with others be enforced, and (2) can a state effectively regulate the behavior of parties with whom it contracts by basing its choice of partners on their past record of dealing with others in the state.

To prevent the state from preferring its own citizens in transactions, a court would have to order the state to contract with parties that the state never intended to deal with. But where the state attempts to impose preferences by requiring persons who buy or sell from it to prefer its citizens, the court could treat the contract clause as invalid without necessarily having to command the state to do anything. Promisees often enforce promises by going to court or threatening to do so. Invalidation of a resident preference contract term could be a defense to a breach of contract claim. If the court withholds its support for the state's claim, the result is inaction rather than an order requiring the state to do something. The state would not be regulated directly by the federal government--just preempted by the conflicting federal policy from using the legal system to enforce its will on private individuals.

On the other hand, the state may be a defendant in contract term litigation where a court has applied the dormant Commerce Clause as the basis for an order against a state official's behavior. ${ }^{184}$ In the injunction suit, the court declares the unenforceability of the term which, like other regulations invalidated by the dormant Commerce Clause, justifies an injunction against state enforcement: the court basically says that it will not enforce the clause, and does so in a way that determines the issue

182. South-Central Timber v. Wunnicke, 467 U.S. 82,99 (1984).

183. White, 460 U.S. at 213.

184. South-Central Timber, 467 U.S. at 85-87. 
early enough to enable the parties to plan their course of action. ${ }^{185}$ Thus, South-Central Timber Corporation sought an injunction against Wunnicke, the Commissioner for Department of Natural Resources of Alaska, to prevent the state from putting a clause in the terms of a bid for stateowned timber that would require purchasers to process the timber within the state. ${ }^{186}$ The state resisted on the grounds that it could contract as it wished, but a plurality of the Court condemned the contract term as "downstream regulation." 187

South-Central Timber may have sought the injunction because it feared that the state would use the local processing term as a condition of its performance of the contract. If the state enforces a local preference condition by refusing to deliver the goods or service to the purchaser or by refusing to pay for goods or services received, the resulting lawsuit would seek to order the state to perform. Because contracts are founded on the agreement of the parties, courts may strike a provision but remain reluctant to remake the contract by changing other terms of the transaction. Thus, if the dormant Commerce Clause invalidates the legal effect of the clause in the contract, it leaves the litigants in the posture they would have been in without such a clause. In a suit for damages or for specific property, the Eleventh Amendment and sovereign immunity bar the suit unless the state has waived its immunity. ${ }^{188}$ However, the state might waive its immunity in contract actions in order to induce businesses to deal with it. Thus, the "confrontation" between the state and the federal policy against protectionism in contract term litigation would occur in a context to which the state consented.

Litigation posture should not determine the validity of a term. If the clear statement rule requires a court to find that the state may not be enjoined from putting a term in a contract, it should also preclude the party who agreed to the term from being able to defend against its enforcement on the grounds that it is invalid. If the clear statement rule does not apply to a private party's claim that the dormant Commerce Clause prevents a clause from being valid against it, that party should be able to enjoin the state from enforcing the clause. Its application should depend on its func-

185. Id.

186. Id. at $85-86$.

187. Id. at 99 .

188. See Edelman v. Jordan, 415 U.S. 65, 6731 (1974) (finding an Eleventh Amendment bar to damages in suits for harm done in the past, but not to prospective relief); Fla. Dep't of State v. Treasure Salvors, Inc., 458 U.S. 670, 684 (1982) (finding Eleventh Amendment bar to suit for specific item in possession of the state); Seminole Tribe of Fla. v. Florida, 517 U.S. 44, 54 (1996) (holding that Congress cannot use commerce power to abrogate Eleventh Amendment immunity of the states); Alden v. Maine, 527 U.S. 706, 755 (1999) (holding that unless state waives it, sovereign immunity precludes Congress from forcing a state to be sued in its own court system). 
tion and rationale. The clear statement rule protects the autonomy of state operations. ${ }^{189}$ Thus, the core question should be whether invalidating the term would control the state's choice of trading partner.

The distinction between a contract term and the choice of a contract partner is blurred. Where the contracting party does not behave in the manner the state requests, the state could claim that it is not dealing with the kind of person it intended. But the Court plurality in South-Central Timber treated the attempt to control another party's future behavior through contract as different from the identity of the party. ${ }^{190}$ The exception is when the persons actually doing the work directly for the state differ from the persons the state contracted for. This was the problem in White, where the city sought to favor local residents on its construction projects. ${ }^{191}$ The contract term would have governed the private contracting party's behavior in hiring its employees who actually built the city's buildings. ${ }^{192}$ The Council of Construction Employers sought declaratory and injunctive relief against the executive order and succeeded in the Massachusetts court, but the Supreme Court reversed, saying that the employees of the construction company were at least in an informal sense "working for the city," and that formal privity of contract should not control. ${ }^{193}$

When a contract term does not determine who does the work or produces the goods under the contract but rather restricts the contracting ability of the person dealing directly with the state, the term is more remote from the Court's concern with protecting the state's choice of trading partner.

Judge Calabresi has suggested that courts should "scrutinize the transaction to determine whether the state is acting more like an ordinary participant in the commercial market or more like a regulator trying to achieve an otherwise unconstitutional purpose by attaching conditions to its commercial transactions." ${ }^{\text {,94 }}$ Where a government entity entered into a requirements contract for waste disposal that by its nature precluded the other parties from using waste hauling companies that would take the waste elsewhere, the Second Circuit upheld the contract on the basis of the market participant exception. ${ }^{195}$ Such requirements contracts employ

189. See David Next Friend Lashonda D. v. Monroe County Bd. of Educ., 526 U.S. 629, 686 (1999) (Kennedy, J., dissenting).

190. South Central Timber, 467 U.S. at $95-96$.

191. White v. Mass. Council of Constr. Employers, Inc., 460 U.S. 204, 205-06 (1983).

192. Id. at 205 n.1.

193. Id. at 211 n.7.

194. Inc. Vill. of Rockville Ctr. v. Town of Hempstead, 196 F.3d 395, 399-400 (2d Cir. 1999).

195. See $i d$. at $400 \mathrm{n.} .8$ (including the contract in question among "ordinary market transactions that qualify for the market participant exception"). 
common economic terms that relate to the commercial concerns of the parties to the contract. ${ }^{196}$

Calabresi's suggestion makes perfect sense as a means of distinguishing between contract terms that carry out the choices of a market participant and those that reflect the state government's interest in protecting its citizens at the expense of interstate commerce, but his distinction does not explain the decision in White. "Key person" provisions make sense in a commercial contract, but local residency is not a normal commercial concern. However, the state should be free to choose its trading partners, and that includes looking through the business structure to choose who actually performs the work that the contract calls for.

This concern with choice of a trading partner also applies to the invalidation of normal commercial contract terms. If the state cannot impose the term in its contract, it is forced to contract with a private company that can. ${ }^{197}$ Private businesses have little reason to favor in-state businesses over out-of-state businesses, so a term common to commercial transactions is unlikely to reflect the protectionist purposes forbidden by the dormant Commerce Clause. The combination of these factors should lead courts to uphold normal commercial contract terms in state contracts against dormant Commerce Clause challenges.

The Court's decision to invalidate downstream regulations will not preclude states from accomplishing the same result. The state may simply announce a policy that it will refuse to deal with any party that does not continue to deal exclusively within the state. It would enforce the policy by its own purchase and sale decisions without recourse to the court or to any contractual provision. Any attempt to forbid this behavior would involve an order by the court to the state requiring it to make a specific purchase or sale. This is the direct regulation forbidden by the clear statement rule. Where the state does not impose the preference by contract, but simply chooses to do business with companies that have previously acted in a way that preferred local industry, its behavior could

196. Id. at 399-400.

197. The Court used the dormant Commerce Clause to strike down an ordinance that required all solid waste to be processed at a private transfer station that would ultimately belong to the town. The town effectively agreed to use its regulatory power to get a private business to build the facility. C \& A Carbone v. Clarkston, 511 U.S. 383, 394 (1994). The dissenters argued that the ordinance was not protectionist in purpose or effect. Id. at 430 (Souter, J., joined by Rehnquist, C.J., and Blackmun, J., dissenting). The majority concluded, however, that the ordinance was discriminatory because it prevented competition in waste processing from out of state. $I d$. at 392 . Justice O'Connor concurred on the basis that the ordinance imposed an excessive burden on interstate commerce in relation to the local benefits. Id. at 407 (O'Connor, J., concurring). The majority acknowledged that the town could instead have provided a subsidy for the local station. Id. at 394 . In that vein, it could also have hauled all of the residents' trash without charge and paid a fee to the waste processing station under a requirements contract. 
have much the same economic effect as a contract clause. But any attempt to make the state contract with other companies would force the state to act in a way that it has not consented to. For that reason, although a court could invalidate a contract term that prefers state residents or instate performance, it should not invalidate the same kind of preference used as the basis for choosing a trading partner. The difference is between invalidating a term of an agreement and compelling the state to enter an agreement with a party it does not want to deal with.

Analyzing the market participant doctrine as an analogue to the clear statement rule simplifies its application. The state may discriminate in its own purchase and sale decisions and attempt to assure discrimination by announcing that it will base its decisions in the future on the behavior of contracting parties. Any prohibition on such behavior would be a direct regulation of the state contrary to the policy of the clear statement rule. On the other hand, any attempt to use the contract to force a contracting party to discriminate would be an unenforceable term that does not raise the same issues of state sovereignty, and therefore does not require a clear statement from Congress to invalidate it. Whether a particular term is permissible would depend on ordinary dormant Commerce Clause principles and whether it forecloses a choice of persons with whom the state may deal.

This explanation for the market participation exemption permits states to choose buyers and sellers on the basis of their past behavior even though such a choice would have a regulatory effect-e.g., Alaska can restrict its sales to businesses that have previously processed timber only in Alaska as long as it does not require them to do so in the future.

\section{REMAINING PROTECTIONS FROM STATE MARKET PARTICIPANT DISCRIMINATION}

One objection to this theory of the market participation rule is that a state would have tremendous power to discriminate against citizens of other states and significantly impair the Union. No one much cares about an individual purchase of a gross of post-it pads, but the decision to limit all sales of concrete to citizens of the state may have a dramatic effect. The Constitution does not forbid state enterprises, and a move toward a socialist state in one of the states coupled with discrimination in sales and purchases could be very isolating. If the dormant Commerce Clause does not apply, what protection remains?

The first and most important protection is that Congress may legislate under the Commerce Clause to expressly forbid the states from discriminating against buyers or sellers from other states in the purchase or 
sale of goods. ${ }^{198}$ If the problem is sufficiently severe to disrupt the economy, Congress may deal with it expressly. The dormant Commerce Clause is an efficient mechanism to preclude the necessity for congressional case-by-case involvement with every little regulation-it also warns the states away from protective legislation-but Congress always retains the power to grant or deny state discrimination.

Even if Congress does not act, there are two other relevant provisions of the Constitution: the Privileges and Immunities Clause of Article IV and the Equal Protection Clause of the Fourteenth Amendment. These provisions may guard against the worst abuses by a state that attempts to use its power to discriminate against persons from other states.

\section{A. Article IV Privileges and Immunities}

Article IV's Privileges and Immunities Clause ${ }^{199}$ does not apply to corporations. ${ }^{200}$ Thus, a state may freely discriminate against corporations from other states without worrying about this Clause. It does, however, protect citizens of other states. Thus, it may be called into play whenever a state conditions its purchases or sales on the citizenship of the persons employed by the other party. This is the lesson of White and Camden. In White v. Massachusetts Council of Construction Employers ${ }^{201}$ the Supreme Court held that the dormant Commerce Clause did not apply to an executive order by a mayor that required firms contracting with the city to use city residents to work on city projects. ${ }^{202}$ The following year, in United Building \& Construction Trades Council v. Mayor of Camden, ${ }^{203}$ the Court held that a city ordinance requiring firms working on city construction projects to prefer city workers was subject to the Privileges and Immunities Clause of Article IV. ${ }^{204}$

Article IV does not protect a market economy, but it does require the state to justify any discrimination against citizens of other states, regardless of whether the discrimination is a product of regulation or direct dealings. $^{205}$

198. See U.S. ConST. art. I, $\S 8$, cl. 3 .

199. U.S. ConsT. art IV, $\S 2, \mathrm{cl}$. I ("The Citizens of each State shall be entitled to all Privileges and Immunities of Citizens in the several States.").

200. Waters-Pierce Oil Co. v. Texas, 177 U.S. 28, 45 (1900) (holding that a corporation does not have the rights of its individual members and cannot invoke the Privileges and Immunities Clause).

201. 460 U.S. 204 (1983).

202. Id. at 214-15.

203. 465 U.S. 208 (1984).

204. Id. at $220-21$.

205. For example, Article IV privileges and immunities protect nonresidents from being excluded from state hospitals where there is room and they pay their own costs. See, e.g., Doe v. Bol- 
United Building indicates, however, that a state may be able to justify restricting purchases and sales to companies employing residents. ${ }^{206}$ The case ultimately was remanded to determine whether the economic problems of New Jersey justified the restriction, implying that the city could restrict its payments to its citizens. ${ }^{207}$ United Building suggests that a reflexive preference that excludes out-of-state residents from jobs without a corresponding need for in-state residents would indicate bias and prejudice against outsiders that would harm the Union. ${ }^{208}$ On the other hand, outsiders would readily accept each state's use of its own resources to meet the needs of its own citizens first because they would expect the same from their own state. Thus, a rational basis for state preferences suffices to satisfy the Privileges and Immunities Clause.

\section{B. Equal Protection}

Discrimination against corporations from other states would be governed by the Equal Protection Clause. ${ }^{209}$ Just as the state could not make its purchase and sale decisions on a racial basis without running afoul of the Fourteenth Amendment's equal protection requirement, the Court would examine whether purchase and sale decisions that discriminate against out-of-state companies violate the Equal Protection Clause.

In Metropolitan Life Insurance Co. v. Ward, ${ }^{210}$ the Court used the Equal Protection Clause against a regulation on insurance companies despite federal approval of the state laws, saying that the desire to improve the local economy at the expense of out-of-state companies was not a legitimate governmental interest. ${ }^{211}$ On the other hand, the Court simultaneously upheld a regional banking law that discriminated against companies from outside the region as rationally based, ${ }^{212}$ finding that concern for local control of banking institutions was a plausible legitimate interest of the state. ${ }^{213}$

In general, the decision to favor a local company will be seen as a rational one that does not violate equal protection, but the Court may nevertheless retain its power to invalidate the law in extreme cases that seem disruptive of the Union.

ton, 410 U.S. 179, 200 (1973) (holding that the Privileges and Immunities Clause requires state hospitals that perform abortions for state residents to perform them on out-of-state residents).

206. United Bldg., 465 U.S. at 222-23.

207. Id. at 223 .

208. Id.

209. U.S. ConsT. amend. XIV, \$ 1 .

210.470 U.S. 869 (1985).

211. Id. at $882-83$.

212. Ne. Bancorp, Inc. v. Bd. of Governors, 472 U.S. 159, 178 (1985).

213. Id. at $177-78$. 


\section{SUMMARY AND CONCLUSION}

Recognizing that the market participant doctrine is a variant of the clear statement rule with respect to the federal regulation of state government makes the rule more readily understood and its integration into the Court's prior Commerce Clause jurisprudence more clear. The doctrine protects the state and federal governments from confrontation without a deliberate congressional decision that such a confrontation is necessary. Congress retains the power to legislate where state behavior threatens the Union, and the Privileges and Immunities Clause of Article IV protects individuals from other states. Finally, the Equal Protection Clause of the Fourteenth Amendment may be used to prevent the worst abuses of state power that lack any legitimate justification. 